\title{
PHAGE TYPES OF SALMONELLA ENTERITIDIS ISOLATED FROM CLINICAL AND FOOD SAMPLES, AND FROM BROILER CARCASSES IN SOUTHERN BRAZIL
}

Luciana Ruschel dos SANTOS(1), Vladimir Pinheiro do NASCIMENTO(1), Sílvia Dias de OLIVEIRA(1), Dália P. RODRIGUES(2), Eliane Moura Falavina dos REIS(2), Liliane Miyuki SEKI(2), Aldemir Reginato RIBEIRO(1) \& Sueli A. FERNANDES(3)

\begin{abstract}
SUMMARY
272 isolates of Salmonella Enteritidis (111 isolated from frozen broiler chicken carcasses, 126 from human food and other biological materials involved in food poisoning outbreaks and 35 from different poultry materials) were selected for phage typing. From these, 111 were phage typed, $57.65 \%$ being classified as phage type $4,32.43 \%$ as phage type $4 \mathrm{a}, 3.60 \%$ as phage type $6 \mathrm{a}$ and $0.90 \%$ as phage type 7 , whereas $5.40 \%$ samples were not phage typeable. The predominance of phage type 4 is in agreement with the results published worldwide, and reinforces the need for studies related to the epidemiological meaning of these findings.
\end{abstract}

KEYWORDS: Salmonella Enteritidis; Phage typing; Human food; Broiler carcasses.

\section{INTRODUCTION}

The salmonellosis is recognized as being a common cause of human food poisoning outbreaks (FPOs), thus representing an important concern to the public health, not only in developed countries, but especially in developing ones.

A dramatic increase in the number of FPOs in the State of Rio Grande do Sul (Brazil) were reported by the local press in the period between 1994 and 1995, most of them with clinical diagnostic of salmonellosis. In the majority of the cases, the ingestion of poultry meat products or egg-containing foods such as home-made mayonnaise was implicated in the outbreaks. During the same period, the determination of a Salmonella contamination index in broiler carcasses, carried out by the Center for Diagnostics and Research in Avian Pathology (CDPA) Faculty of Veterinary Medicine, Federal University of Rio Grande do Sul (UFRGS), Brazil, was able to determine that $17.5 \%$ from the 1,300 carcasses examined were positive to Salmonella sp. ${ }^{7}$.

Among the serovars involved in FPOs, Salmonella Enteritidis (SE) is the most detected one ${ }^{6}$. Outbreaks of illnesses transmitted by SE contaminated food were also related in the USA and in many European countries since the end of the 70 decade, usually related to the consumption of products containing raw or semi-raw eggs. Nevertheless, the presence of Salmonella sp. in broiler meat has never been ignored ${ }^{10}$.

Poultry products are frequently indicated as the source of gastrointestinal infections in humans, mainly when SE or $S$. Typhimurium are involved. ${ }^{9}$ However, this relationship remains obscure, because it lacks the precise identification of the serovar, and so it represents a critical point for the success of epidemiological investigations, which aim the prevention of infection as well as the eradication of its sources.

The epidemiological studies of SE infections demand typing methods that are capable to discriminate and to separate samples not related one to another. For this purpose, one of the main methods used is the phage typing. Since 1950, the phage typing technique has been the chosen method to differentiate bacterial serovars at the reference laboratories. The pitfalls are that the technique presents restrictions regarded to costs, being time demanding and also needing specialized staff, added to the fact that not all the Salmonella sp. samples are phagetypeable ${ }^{11}$.

In this study, samples of SE isolated from poultry materials and from cases FPOs occurred in the State of Rio Grande do Sul, Brazil were selected, aiming to identify the phage types involved and their correlation.

\section{MATERIALS AND METHODS}

SE strains: Two hundred and seventy two (272) SE isolated samples were selected, from which 111 were isolated from frozen broiler carcasses, 126 from biological materials from humans and human food involved in FPOs and 35 from different sources of poultry materials.

The SE samples were isolated from broiler carcasses produced in Poultry Companies located at the highlands region of the State, which were all submitted to a microbiological monitoring programme, carried out during the years 1995 and 1996 by the CDPA-UFRGS. During this 


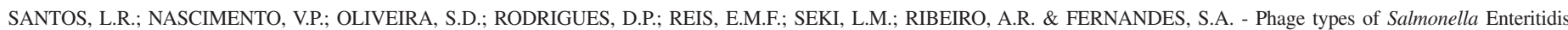
isolated from clinical and food samples, and from broiler carcasses in Southern Brazil. Rev. Inst. Med. trop. S. Paulo, 45(1):1-4, 2003.

period, 1,344 carcasses were analyzed, from which 203 were positive for Salmonella sp. (111 of the latter identified as SE). The methodology for Salmonella sp. detection preconized by the Brazilian Ministry of Agriculture $^{2}$ was used, including the antigenic characterization of the Salmonella sp. genus, while the complete serovar determination was performed by the Enteric Pathogens Lab from the Oswaldo Cruz Institute, Rio de Janeiro (OCI-RJ).

The SE samples isolated in FPOs were supplied by the Bacteriology Lab from the Central Laboratory belonging the State of Rio Grande do Sul Production and Research in Public Health Foundation (LACEN/ FEPPS/Porto Alegre, RS). These samples were originated from different regions of the State and obtained between the years 1995 and 1996, being 66 isolated from human food (vegetables, cheeseburger, sweet cake, etc) and 60 from human biological materials (1 LCR, 1 haemoculture). These samples were antigenically characterized at the Adolfo Lutz Institute, São Paulo.

Finally, the samples of SE isolated from different poultry materials were obtained between the years 1999 and 2000 from a private animal laboratory from the State of Santa Catarina. The latter were also characterized at the OCI-RJ.

Phage typing (adapted from WARD et al. ${ }^{11}$ ): One hundred and eleven (111) samples of SE were selected to perform the phage typing technique, which was accomplished at the OCI-RJ. Initially, SE samples previously stored in stocking agar were inoculated into buffered peptone water $0.5 \%$ (BPW-Merck) and incubated at $37{ }^{\circ} \mathrm{C}$ for 24 hours. After, BPW aliquots were streaked in Hektoen agar (Merck) and incubated at $37{ }^{\circ} \mathrm{C}$ for 24 hours. Compatible colonies were then selected and inoculated into Costa and Vernin medium, Sulfur Indol Motility (SIM), lysine broth and nutrient agar (Merck), which were all incubated as previously indicated. The biochemical profile of the samples was then verified, after which the serology for the antigenic characterization of SE was performed.

For phage typing, each sample previously inoculated in the SIM medium was then inoculated in tubes with $1.5 \mathrm{~mL}$ of phage broth and incubated, with agitation, at $37^{\circ} \mathrm{C}$ for an average of two hours. After this period, samples with turbidity compatible with 0.5 in the MacFarland scale were checked in a photocolorimeter, after which the selected phage broths was poured on phage agar plates, which were then homogenized, and from which the excess of fluid was removed with the use of a sterile pipette. After that, the plates were left drying up for 20 minutes. Finally, $10 \mu \mathrm{L}$ from each one of the 10 selected phage solutions were poured into plates previously divided in ten quadrants, which were incubated at $37{ }^{\circ} \mathrm{C}$ for 24 hours. The reading of the results were performed after this period.

\section{RESULTS AND DISCUSSION}

After the phage typing of the 111 isolates of SE (Table 1), results indicated that $57.65 \%$ of the samples corresponded to the phage type PT $4,32.43 \%$ to the PT $4 \mathrm{a}, 3.60 \%$ to the PT $6 \mathrm{a}$ and $0.90 \%$ to the PT 7, while $5.40 \%$ samples were classified as not phage typeable (RDNC: reagent do not conform).

Regarding the SE isolated from human biological materials, it was verified that $66.66 \%(4 / 6)$ samples obtained from food handlers were identified as PT 4 and $33.33 \%(2 / 6)$ as PT 4 a. From the samples isolated from nosocomial cases, $54.54 \%$ could be classified as PT $4(6 / 11)$ and $45.45 \%$ as PT $4 \mathrm{a}(5 / 11)$. The single sample from the cerebral spinal fluid was identified as PT 4, while the sample from haemoculture corresponded to the phage type PT 4a. The specific samples 728/96 and $1665 / 95$ fitted in the PT 4a and 6a, respectively.

Table 1

Distribution of the $S$. Enteritidis phage types according to the sample source and isolation period

\begin{tabular}{|c|c|c|c|c|c|c|c|c|}
\hline \multirow[t]{2}{*}{ Period } & \multirow[t]{2}{*}{ Source } & & \multicolumn{6}{|c|}{ Phage type } \\
\hline & & & 4 & $4 \mathrm{a}$ & $6 a$ & 7 & RDNC & Total \\
\hline \multirow[t]{3}{*}{ 1995-1997 } & Food & Without poultry components & 3 & 4 & - & - & - & 7 \\
\hline & & With poultry components & 17 & 6 & 1 & - & - & 24 \\
\hline & & Undefined & - & 1 & - & - & - & 1 \\
\hline \multirow[t]{5}{*}{ 1995-1997 } & Human & Handlers & 4 & 2 & - & - & - & 6 \\
\hline & & Nosocomials & 6 & 5 & - & - & - & 11 \\
\hline & & LCR & 1 & - & - & - & - & 1 \\
\hline & & Haemoculture & - & 1 & - & - & - & 1 \\
\hline & & Avulse & - & 1 & 1 & - & - & 2 \\
\hline 1995-1996 & Broiler carcasses & & 28 & 2 & - & - & - & 30 \\
\hline \multirow[t]{2}{*}{ 1999-2000 } & Poultry Source & & 5 & 14 & 2 & 1 & 6 & 28 \\
\hline & Total & & $64(57.65 \%)$ & $36(32.43 \%)$ & $4(3.6 \%)$ & $1(0.9 \%)$ & $6(5.4 \%)$ & $111(100 \%)$ \\
\hline
\end{tabular}

LCR: Cerebral Spinal Fluid 


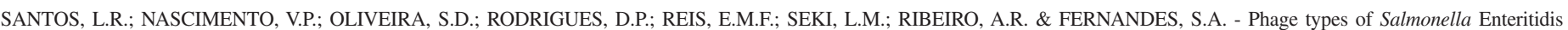
isolated from clinical and food samples, and from broiler carcasses in Southern Brazil. Rev. Inst. Med. trop. S. Paulo, 45(1):1-4, 2003.

From the feed samples containing poultry material in their formulation, $70.83 \%(17 / 24)$ were identified as PT 4, 25\% (6/24) as PT 4a and $4.16 \%(1 / 24)$ as PT 6 a. The samples of SE originated from feed deprived of poultry products in their composition corresponded to the PT 4a $(57.14 \%$; 4/7) and PT $4(42.85 \% ; 3 / 7)$. The sample 674/96 (roasted chicken and barbecue) was identified as PT $4 \mathrm{a}$.

The phage typing performed in the SE isolated from broiler carcasses showed that $93.33 \%$ of the samples belonged to the PT $4(28 / 30)$ and $6.66 \%$ to the PT $4 \mathrm{a}(2 / 30)$.

The samples of SE isolated from different poultry materials were identified as PT 4a $(50 \% ; 14 / 28)$, PT $4(17.85 \% ; 5 / 28)$, PT 6a $(7.14 \%$; $2 / 28)$ and PT $7(3.57 \% ; 1 / 28)$, while $21.42 \%(6 / 28)$ from the samples were considered as being not phage typeable.

The predominance of SE PT 4 and of its derivative PT 4a in the samples isolated in the State of Rio Grande do Sul presented in this paper is in agreement with other results published worldwide. According to PRAT et $a l .{ }^{8}$, the phage typing of SE isolates have been concentrated mainly in developed countries of Europe, Asia, North America and Australia, with little information being provided from developing countries. For this author, the phage type distribution presents a clear geographic variation, with the predominance of the PTs 4, 1, 6 and 8 in Europe and of the PTs 4, 8 and 13a in Canada. The United States present a similar profile, with predominance of the PTs 8, 13a, 13, 14b and with a lower frequency of the PTs 4 and 1 . According to MARÉ et al. ${ }^{6}$, the PT 4 is also particularly predominant in Germany, Italy and The United Kingdom. In Poland, most of the PTs identified are 7, 1 and 6. In South Africa, from the 557 SE samples received by the National Reference Institute, $44 \%$ were identified as PT 34, 38\% as PT 4, 12\% as PT 14 and the $6 \%$ remaining as the PTs $1,7 \mathrm{a}, 24,14 \mathrm{~b}$ or $9 \mathrm{a}$. However, the information about SE phage types in other regions of the world are very limited. SE outbreaks in humans have been reported in Argentina, but so far no study about the phage type of these isolates has been published.

In Brazil, a paper from IRINO et al. ${ }^{4}$ reports the phage typing of 574 SE samples, from which 383 were isolated from human sources in the period between 1975 and 1995, in the State of São Paulo, Brazil. The analysis revealed that $80.9 \%$ from the samples isolated during the period ranging from 1975 to 1992 could be classified as PT 8, while $65.2 \%$ of the samples isolated in 1993 fitted in as PT 4. In 1994 and 1995, the PT 4 percentual share was $99.75 \%$ and $98.4 \%$, respectively. According to the authors, these results suggest that the significant increase in SE occurrence in the State of São Paulo could be associated to a general PT 4 increase, appearing to be related to breeders importation from European countries, which may have made easier the introduction and dissemination of PT 4 SE, especially since 1993.

In fact, the causes for the increment of presence of PT 4 SE are not clear. Some authors have postulated that samples of this phage type would be more invasive in young birds, making the transmission through ovary to the next generations easier. Whatever the mechanism may be, the reports of SE incidence suggest that SE PT 4 introduced itself quickly, infecting either birds or humans, remaining as a dominant sample in these populations ${ }^{1}$.

The agreement among the PTs of interest for human medicine and of those identified in foods connected to FPOs and in poultry samples stresses the role of the poultry production in the epidemiology and transmission of SE infections. It is paramount to take into considerance the importance of an eventual SE presence in the cloaca and ovary from laying hens, as well as the relevance of vertical contamination in the epidemiology of these infections. This kind of contamination reinforces the expansion of the control of SE infections, which have to be put beyond a simple washing or disinfection of the eggshells ${ }^{3}$.

However, the direct relationship between PT 4 and birds is quite blunt. In this sense, a paper from LACONCHA et al. ${ }^{5}$ reports the phage typing of samples not epidemiologically related, showing a predominance of the PT 4, despite other phage types having also been identified. The PT 4 was isolated from foods as diverse as eggs, chicken meat, cattle meat, black pepper and a number of other sources, what could be interpreted as a reflex of the diffusion of these types across various ecological niches. Some PT 4 samples were also recovered from water (with or without fecal contamination) used for fishing or recreation activities. For these authors, the information relative to presence of this phage type in these reservoirs is insufficient, and there is a possibility of new transmission chains coming out through the consumption of raw fish or related foods.

In any case, the phage typing reveals itself an important epidemiological tool, either to trace relationships between samples, or eventually to discard an implicated source. In a monitoring survey of SE performed by REIS in 1994, all the samples isolated from birds belonged to the PT 4, while the human originated samples from the same geographic region, were predominantly classified as PT 8. For the author, these findings would be an indicative that the SE samples, recognized on that occasion as the main agent from one FPO, would probably not be transmitted by poultry or their products ${ }^{3}$.

The findings of the present paper provide relevant data in relation to the PT 4 occurrence between the samples analyzed. The predominance of this phage type is in accordance with the worldwide level of occurrence, and reinforces the need for further studies relatively to the causes of this increase and to the real significance of the presence of this phage type in our environment.

\section{RESUMO}

\section{Fagotipos de Salmonella Enteritidis isoladas de amostras clínicas,} alimentos e carcassas de frangos no sul do Brasil

Neste trabalho utilizou-se 272 isolados de Salmonella Enteritidis, dos quais 111 foram isolados de carcaças de frango congeladas, 126 de alimentos e material biológico de humanos envolvidos em episódios de toxinfecções alimentares e 35 de diferentes materiais de origem avícola.

Destas amostras, 111 foram fagotipadas, sendo 57,65\% classificadas como fagotipo $4,32,43 \%$ como fagotipo $4 a, 3,60 \%$ como fagotipo 6 a e $0,90 \%$ como fagotipo 7 , enquanto $5,40 \%$ das amostras não foram fagotipáveis.

A predominância do fagotipo 4 está em concordância com os resultados publicados ao redor do mundo, e reforça a necessidade de estudos relacionados ao significado epidemiológico destes achados. 
SANTOS, L.R.; NASCIMENTO, V.P.; OLIVEIRA, S.D.; RODRIGUES, D.P.; REIS, E.M.F.; SEKI, L.M.; RIBEIRO, A.R. \& FERNANDES, S.A. - Phage types of Salmonella Enteritidis isolated from clinical and food samples, and from broiler carcasses in Southern Brazil. Rev. Inst. Med. trop. S. Paulo, 45(1):1-4, 2003.

\section{ACKNOWLEDGEMENTS}

The authors wish to thank the professionals from the Center for Diagnostics and Research in Avian Pathology (CDPA-UFRGS), the Bacteriology Lab staff from the State of Rio Grande do Sul Production and Research in Public Health Foundation (LACEN/FEPPS/Porto Alegre, RS), the Enteric Pathogens Laboratory, Adolfo Lutz Institute and the Enteric Pathogens Laboratory, Oswaldo Cruz Institute. This research work was partially financially supported by the State of Rio Grande do Sul Research Support Foundation (FAPERGS) and by Brazilian National Council for Scientific and Technological Development (CNPq).

\section{REFERENCES}

1. BOYCE, T.G.; KOO, D.; SWERDLOW, D.L et al. - Recurrent outbreaks of Salmonella Enteritidis infections in a Texas restaurant: phage type 4 arrives in the United States. Epidem. Infect., 117: 29-34, 1996.

2. BRASIL. Ministério da Agricultura e Abastecimento. Secretaria de Defesa Agropecuária. Portaria n. 126, de 03 de novembro de 1995. Normas para Credenciamento e Monitoramento de Laboratórios de Diagnóstico das Salmoneloses Aviárias ( $S$. Enteritidis, $S$. Gallinarum, $S$. Pullorum e $S$. Typhimurium). Diário Oficial da República Federativa do Brasil, Brasília, n. 212, p. 1182-1184, 06 nov. 1995. Secção I.

3. HOFER, E.; SILVA FILHO, S.J. \& REIS, E.M. - Prevalência de sorovares de Salmonella isolados de aves no Brasil. Pesq. vet. bras., 17: 55-62, 1997.

4. IRINO, K.; FERNANDES, S.A.; TAVECHIO, A.T.; NEVES, B.C. \& DIAS, A.M.G. Progression of Salmonella Enteritidis phage type 4 strains in São Paulo State, Brazil. Rev. Inst. Med. trop. S. Paulo, 38: 193-196, 1996.
5. LACONCHA, I.; LÓPEZ-MOLINA, N.; REMENTERIA, A. et al. - Phage typing combined with pulsed-field gel electrophoresis and random amplified polymorphic DNA increases discrimination in the epidemiological analysis of Salmonella enteritidis strains. Int. J. Food Microbiol., 40: 27-34, 1998.

6. MARÉ, L.; DICK, L.M.T. \& van der WALT, M.L. - Characterization of South African isolates of Salmonella Enteritidis by phage typing, numerical analysis of RAPDPCR banding patterns and plasmid profiles. Int. J. Food Microbiol., 64: 237-245, 2001 .

7. NASCIMENTO, V.P.; SILVA, A.P. \& SALLE, C.T.P. - Ocorrência de Salmonella sp. em carcaças de frangos industrialmente processadas. In: CONFERÊNCIA APINCO, 1996, Curitiba, Fundação APINCO de Ciência e Tecnologia Avícolas, 1996. Anais. p. 81.

8. PRAT, S.; FERNÁNDEZ, A.; FICA, A. et al. - Tipificación fágica de aislados de Salmonella Enteritidis de muestras clínicas, alimentarias e avícolas en Chile. Rev. panamer. Salud públ., 9: 7-12, 2001.

9. SANTOS, D.M.S.; BERCHIERI Jr., A.; FERNANDES, S.A.; TAVECHIO, A.T. \& AMARAL, L.A. - Salmonella em carcaças de frango congeladas. Pesq. vet. bras. 20: $39-42,2000$

10. THRELFALL, E.J. \& FROST, J.A. - The identification, typing and fingerprinting of Salmonella: laboratory aspects and epidemiological applications. J. appl. Bact., 68: 5-16, 1990.

11. WARD, L.R.; de SA, J.D.H. \& ROWE, B. - A phage typing scheme for Salmonella enteritidis. Epidem. Infect., 99: 291-294, 1987.

Received: 23 May 2002

Accepted: 26 December 2002 